\title{
PRINSIP KESANTUNAN DALAM FUNGSI TINDAK TUTUR ILOKUSI FILM EIN FREUND VON MIR DAN KOKOWÄÄH
}

\author{
Mirfat \\ Universitas Negeri Surabaya \\ mirfatmirfat@mhs.unesa.ac.id \\ Diterima: 30 Mei 2018 \\ Publikasi: 27 Februari 2019 \\ DOI: http://dx.doi.org/10.32528/bb.v4i1.1870
}

\begin{abstract}
ABSTRAK
Penelitian ini mengkaji tindak tutur yang ada pada dialog antartokoh dalam film "Ein Freund von mir dan Kokowääh" yang meliputi (1) jenis tindak tutur ilokusi, (2) fungsi tindak tutur ilokusi, (3) prinsip kesantunan, dan (4) skala kesantunan. Penelitian kualitatif ini, menggunakan metode dokumentasi untuk mengumpulkan data. Melalui metode agih, jenis dan fungsi tindak tutur ilokusi dapat ditentukan. Untuk meneliti prinsip kesantunan dan skala kesantunan menggunakan metode padan pragmatis. Hasilpenelitianmenunjukkanbahwa:(1) pada film Kokowääh jenis tindak tutur yang ditemukan adalah asertif/representatif, ekspresif, direktif, komisif, dan deklarasi, sedangkan pada film Ein Freund von mir yang ditemukan adalah jenis tindak tutur asertif/representatif, direktif, ekspresif, komisif, dan deklarasi. (2) fungsi tindak tutur ilokusi yang didapat mempunyai jumlah berbeda-beda bergantung pada jenis tindak tutur ilokusinya baik pada film Kokowääh maupun pada film ein Freund von mir. (3) prinsip kesantunan yang paling banyak digunakan dalam film "Kokowääh"yaitu maksim kearifan, pujian, kedermawanan, kerendahan hati, dan kesimpatisan, sedangkan dalam film "Ein Freund von mir" adalah maksim pujian, kedermawanan, kearifan, kerendahan hati, dan kesimpatisan. (4) skala kesantunan yang digunakan adalah skala kemanasukaan dengan hasil didominasi oleh skala kemanasukaan tinggi. Maka dari itu dapat disimpulkan bahwa tuturan-tuturan dalam kedua film tersebut banyak berupa pernyataan yang mempunyai fungsi yang berbeda-beda tergantung dengan konteks di mana tuturan tersebut terjadi. Dari tuturan-tuturan tersebut diketahui bahwa maksim kesepakatanlah yang banyak digunakan dalam bersopan santun dengan skala kesantunan kemanasukaan tinggi, di mana lawan tutur dapat dengan bebas menentukan tindakan berikutnya.
\end{abstract}

Kata Kunci: tindak tutur ilokusi, fungsi tindak tutur ilokusi, prinsip kesantunan, skala kesantunan.

\begin{abstract}
Pragmatics is the study of meaning which is spoken by the speaker or the writer and translated by the listener or the reader. According to speech act, the behavior which is shown with speech will result three connected speech acts. Those speech acts are locutionary act, illocutionary act and perlocutionary act. Among three kind of speech acts, illocutionary act has types and functions in creating communication. This study is to analyze the speech act in the dialog of the characters in movies ein Freund von mirandKokowääh which include (1) types of illocutionary act, (2) function of illocutionary act, (3) politeness principle, and (4) politeness scale.Thisqualitativeresearch uses documentation method in collecting the data from the dialogue of the main character in movies ein Freund von mirandKokowääh. By using agih methodology, types and function of illocutionary act can be determined. Politeness principle and scale are approached by pragmatic equivalent methodology. The result of the study shows that (1)In Kokowääh, the types of speech act are assertive/representative, expressive, directive, commissive,
\end{abstract}




\begin{abstract}
and declarative and in Ein Freund von mir are assertive/representative, directive, expressive,commissive, and declarative,(2) The function of illocutionary act has different amount which depends on types of illocutionary act to Kokowääh or ein Freund von mir,(3) politeness principle which is the most spoken in both films is agreement maxim followed by others. In Kokowääh are tact, approbation, generosity, modesty, and sympath maxim, and in Ein Freund von mir areapprobation, generosity, tact, modesty, and sympath maxim.(4)the scale of politeness used is the scale of preference with the result is dominated by high preference scale. Therefore it can be concluded that the speeches in both films has many statements that have different functions depending on the context in which the speech occurs. From the speeches it is known that the maxim of the agreement is widely used in politeness with the high of preference politeness scale, where the interlocutor can be freely decides the next action. Therefore it can be concluded that the speeches in both films has many statements that have different functions depending on the context in which the speech occurs. From the speeches it is known that the maxim of the agreement is widely used in politeness with the high of preference politeness scale, where the interlocutor can be freely decides the next action

Keywords : illocutionary act, function of illocutionary act, politeness principle, politeness scale.
\end{abstract}

\section{PENDAHULUAN}

Menonton film dapat digunakan sebagai sebuah cara untuk mendapatkan contoh pemakaian sebuah bahasa dengan tepat. Tuturan-tuturan dalam dialognya dapat bermanfaat dalam pembelajaran bahasa dari segi pragmatiknya. Pragmatik sendiri adalah ilmu yang mempelajari tentang tuturan. Yule (2006:3) menyatakan bahwa Pragmatik adalah studi tentang makna yang disampaikan oleh penutur (atau penulis) dan ditafsirkan oleh pendengar (atau pembaca). Ada dua hal mendasar yang berhubungan dengan tuturan, yaitu tindak tutur dan peristiwa tutur. Searle (1997:16) menegaskan bahwa tindak tutur adalah produk atau hasil dari suatu kalimat dalam kondisi tertentu dan merupakan kesatuan terkecil dari komunikasi bahasa. Sehubungan dengan tindak tutur ini, Austin (1962:98 - 101) menyatakan terdapat tiga macam tindak tutur, yaitu (1) tindak tutur lokusi, (2) tindak tutur ilokusi, dan (3) tindak tutur
perlokusi.Hubungan antara ketiga tindak tutur di atas tidak dapat dipisah antara satu dan lainnya. Tindak tutur lokusi sebagai sebuah penyataan yang makna tuturannya diterjemahkan secara harfiah sesuai makna kalimat tersebut. Tindak tutur ilokusi merupakan tindak tutur yang melihat tuturan tersebut dari sudut pandang penutur. Yang ketiga adalah tindak tutur perlokusi, yaitu tindak tutur yang dilihat dari sudut pandang lawan tutur. Hal ini dapat dilihat melalui respon atau reaksi lawan tutur terhadap tuturan yang diterimanya.

Jenis tindak tutur ilokusi menurut Searle contohnya adalah asertif, komisif, direktif, ekspresif, dan deklarasi. Sedangkan fungsi tindak tutur ilokusi tersebut misalnya, kompetitif, menyenangkan, bekerja sama, dan bertentangan (Leech, 1993:162). Agar tujuan berkomunikasi dapat dicapai, diperlukan strategi yang sesuai. Salah satunya prinsip kesantunan. Prinsip kesantunan merupakan prinsip yang mengatur tuturan agar terdengar santun 
oleh lawan bicara.Yule (2006:104) berpendapat bahwa kesantunan dalam suatu interaksi dapat didefinisikan sebagai alat yang digunakan untuk menunjukkan kesadaran tentang wajah orang lain.

Berdasarkan latar belakang di atas, tepat kiranyajika film berjudul "Ein Freund von mir"dan "Kokowääh"digunakan sebagai subyek penelitian ini. Hal ini dikarenakan tuturan dalam kedua film tersebut cukup beragam sehingga menarik untuk diteliti lebih lanjut.Merujuk pada Nadar (2009:108) bahwa sumber data lisan yang tidak natural diperoleh dari film, yang berisi aneka dialog dengan bersandarkan pada kehidupan sehari-hari.

\section{METODE PENELITIAN}

Penelitian ini berupa penelitian kualitatif. Metode yang digunakan dalam penelitian ini adalah metode padan dan metode agih. Menurut Sudaryanto (2015:15), metode padan adalah metode penelitian yang alat penentunya di luar, terlepas, dan tidak menjadi bagian dari bahasa (langue) yang bersangkutan. Hal senada juga diungkapkan oleh Mahsun (2005:114-115) bahwa metode menghubungkan masalah bahasa dengan hal yang berada di luar bahasa dan hal ini dapat terjadi jika unsur ekstralingualnya diandaikan telah tersedia.

Dari lima sub-jenis metode ini menurut Sudaryanto, penelitian ini menggunakan sub-jenis metode pragmatis (Sudaryanto, 2015:17-18), yaitu metode yang menggunakan alat penentu mitra wicara atau mitra tutur.
Sedangkan metode agih (Sudaryanto, 2015:18) adalah metode yang alat penentunya merupakan bagian dari bahasa itu sendiri. Metode ini digunakan untuk mendefinisikan jenis dan fungsi tindak tutur ilokusi dan menentukan bentuk kesopanan dari sebuah tuturan.

Sumber data dalam penelitian ini berupa film berbahasa Jerman dengan judul ein Freund von mir dan Kokowääh. Dasar analisis penelitian ini adalah tuturan-tuturan yang telah diartikan secara tekstual ke dalam bahasa Indonesia. Berikutnya tuturan-tuturan tersebut diberi konteks sesuai dengan adegan dalam film. Peran konteks sangat penting dalam menentukan makna tuturan, sebagaimana yang diutarakan oleh Halliday dan Hasan (dalam Rani, 2006:188) yang mengatakan bahwa konteks wacana adalah teks yang menyertai teks lain. Teks yang menyertai di atas tidak hanya berupa kata-kata (verbal) melainkan juga kejadian-kejadian lainnya dalam keseluruhan teks tersebut. Kejadian-kejadian tersebut dapat berbentuk, situasi, tindakan, suasana, dan hal-hal lainnya yang tidak diucapkan atau dituliskan (noverbal). Brown (1996:38-39) mengutip Hymes, menyebutkan bahwa komponen-komponen tutur yang merupakan ciri-ciri konteks terdiri dari delapan macam, yaitu: (1) penutur (addresser), (2) pendengar (addressee), (3) pokok pembicaraan (topic), (4) latar (setting), (5) penghubung: bahasa lisan/tulisan (channel), (6) dialek/stailnya (code), (7) bentuk pesan (message), dan (8) peristiwa tutur (speech event). Masing- 
masing faktor di atas mendukung terwujudnya suatu wacana.

Teknik pengumpulan data yang digunakan adalah teknik dokumentasi. Teknik dokumentasi merupakan teknik pengumpulan data yang sumber datanya dapat berupa buku, transkrip, catatan, surat, film dan sebagainya. Hal ini sebagaimana diungkapkan oleh Arikunto (2010:274) bahwa metode dokumentasi adalah mencari data mengenai hal-hal atau variabel yang berupa catatan, transkip, buku, surat kabar, majalah, prasasti, notulen rapat, agenda dan sebagainya.

Langkah-langkah pengumpulan data adalah sebagai berikut:

Pertama, dengan menonton dan mencari teori yang berhubungan dengan penelitian. Langkah berikutnya memasukkan tuturan dalam film tersebut ke dalam tabel klasifikasi sebagai berikut:

Tabel klasifikasi 1

\begin{tabular}{|l|l|l|l|l|}
\hline $\begin{array}{l}\text { No. } \\
\text { Data }\end{array}$ & $\begin{array}{l}\text { Waktu } \\
\text { Tuturan }\end{array}$ & $\begin{array}{l}\text { Tuturan } \\
\text { bahasa } \\
\text { Jerman }\end{array}$ & Konteks & Arti \\
\hline 1. & & & & \\
\hline 2. & & & & \\
\hline 3. & & & & \\
\hline
\end{tabular}

Berikutnya adalah memasukkan data tersebut ke tabel klasifikasi 2 untuk menentukan jenis tindak tutur tuturan tersebut bedasarkan kategori Searle. Instrumen penelitian yang digunakan adalah tabel klasifikasi 2 berikut ini:

\section{Tabel klasifikasi 2}

\begin{tabular}{|c|c|c|c|c|c|}
\hline \multirow{2}{*}{$\begin{array}{c}\text { No. } \\
\text { Data }\end{array}$} & \multicolumn{5}{|c|}{ Jenis Tindak Tutur Ilokusi } \\
\cline { 2 - 6 } & 1 & 2 & 3 & 4 & 5 \\
\hline 1. & & & & & \\
\hline 2. & & & & & \\
\hline Jumlah & & & & & \\
\hline
\end{tabular}

Keterangan angka pada tabel di atas:

1 = Jenis tintak tutur Asertif atau Representatif

2 = Jenis tintak tutur Komisif

3 =Jenis tintak tutur Direktif

4 =Jenis tintak tutur Ekspresif

5 =Jenis tintak tutur Deklarasi

Setelah menentukan jenis tindak tutur ilokusi berdasarkan kategori Searle, langkah yang ditempuh adalah menentukan fungsi dari masing-masing jenis tindak tutur tersebut berdasarkan teori dari Leech. Data yang ditemukan dimasukkan ke dalam tabel klasifikasi 3. Berikut tabel klasifikasi 3:

Tabel klasifikasi 3

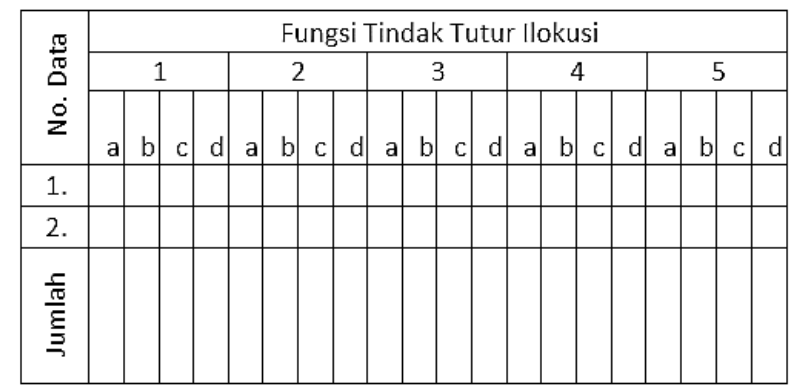

Keterangan angka pada tabel di atas:

$\mathrm{a}=$ Fungsi Kompetitif (Competitive)

$\mathrm{b}=$ Fungsi Menyenangkan

(Convivial)

$\mathrm{c}=$ Fungsi Bekerja Sama

(Collaborative)

$\mathrm{d}=$ Fungsi Bertentangan

(Conflictive)

Adapun keterangan angka $1-5$ dapat dilihat pada tabel klasifikasi 2 sebelumnya. Langkah paling akhir adalah menglasifikasikan bentuk kesopanan berdasarkan prinsip kesopanan Leech. Instrumen penelitian langkah ini berupa tabel klasifikasi 4: 


\section{Tabel klasifikasi 4}

\begin{tabular}{|c|c|c|c|c|c|c|}
\hline \multirow{2}{*}{$\begin{array}{c}\text { No. } \\
\text { Data }\end{array}$} & \multicolumn{6}{|c|}{ Prinsip Kesopanan Leech } \\
\hline & I & II & III & IV & V & VI \\
\hline 1. & & & & & & \\
\hline 2. & & & & & & \\
\hline Jumlah & & & & & & \\
\hline
\end{tabular}

Keterangan tabel di atas adalah sebagai berikut:

I= Maksim Kearifan ( Tact maxim)

II= Maksim Kedermawanan (Generosity maxim)

III= Maksim Pujian (Approbation maxim)

$\mathrm{IV}=$ Maksim Kerendahan Hati (Modesty maxim)

V=Maksim Kesepakatan (Agreement maxim)

$\mathrm{VI}=$ Maksim Kesimpatisan (Sympath maxim)

Langkah-langkah pengumpulan data adalah sebagai berikut:

a. Tahap pencatatan dan pemberian nomor data. Nomor data diberikan sesuai dengan urutan penggalan waktu adegan-adegan yang digunakan sebagai data.

b. Tahap klasifikasi. Tuturan yang diambil sebagai data akan dilihat dari segi jenis dan fungsinya dan selanjutkan akan dilihat dari kacamata prinsip kesopanan.

c. Tahap analisis. Tuturan yang sudah diklasifikan dideskripsikan dengan kata-kata sesuai hasil klasifikasi yang diperoleh.

d. Tahap kesimpulan. Menyimpulkan hasil analisis sesuai denganteori yang digunakan dan rumusan masalah. e. Tahap pelaporan. Memaparkan hasil analisis data yang sudah diperoleh.

\section{PEMBAHASAN}

Data-data yang telah diperoleh dari film Ein Freund von mir dan Kokowääh dibahas secara bertahap sesuai dengan rumusan masalah. Pembahasan pertama adalah bentuk jenis tindak tutur ilokusi dalam percakapan antartokoh dalam kedua film di atas. Pengklasifikasian ini berdasarkan teori dari Searle. Berikutnya dalam pembahasan kedua adalah fungsi tindak tutur ilokusi yang telah diperoleh. Dalam bukunya Prinsip-prinsip Pragmatik (1993:162) Leech mengklasifikan fungsi tindak tutur menjadi empat, yaitu kompetitif, menyenangkan, bekerja sama, dan bertentangan.Dilanjutkan pembahasan ketiga berupa bentuk prinsip kesantunan Leech dalam fungsi tindak tutur ilokusi. Yang terakhir pembahasan keempat mengenai skala kesantunan dari percakapan antartokoh yang didasarkan dari teori Leech.

\section{A. Jenis Tindak Tutur Ilokusi}

\section{1)Tindak tutur asertif/representatif}

Contoh tindak tutur ini dapat dilihat pada tuturan berikut:

(1) Hans (H) : Hast du eine Karre geklaut?

Apa kamu telah mencuri mobil?

Karl (K) : Ich hab inn für eine Woche gemietet.

Aku meminjamnya satu

minggu.

(EFVM.249, 01.09.0301.09.05). 
Tuturan yang diutarakan oleh Karl adalah jawaban atas pertanyaan Hans. Tuturan tersebut berbentuk pernyataan. Tuturan ini jika disisipkan kata-kata ich informiere dir, dass ich ihn für eine Woche gemietet hab, akan nampak bahwa tuturan tersebut berupa kalimat pernyataan yang menunjukkan sebuah informasi yang diminta lawan tutur, maka dari itu tuturan ini dapat digolongkan dalam kelompok jenis tindak tutur ilokusi asertif/representatif.

\section{2)Tindak tutur komisif}

Salah satu contoh diambil dari film Kokowäähsebagai berikut:

(2) Henry (H) : Hm-hm. Versprich mir, dass

du heute keine Spiegeleiermachst. Hallo, versprich's!

$\mathrm{Hm}-\mathrm{hm}$. Berjanjilah padaku,bahwa hari ini kamu tidak membuat telur matasapi. Hallo, berjanjilah!

Magdalena (M): Ich versprech's!

Aku berjanji.

(KKW.566, 01.03.00-01.03.01).

Tuturan ini keluar dari mulut Magdalena ketika Henry memintanya berjanji untuk tidak membuat telur mata sapi lagi. Pada tuturan itu diketahui bahwa Magdalena berjanji untuk tidak melakukannya lagi, maka dari itu tuturan ini dikategorikan dalam jenis tindak tutur komisif karena secara gamblang telah menggunakan kata versprechen 'berjanji' .

\section{3)Tindaktutur direktif}

Dari hasil analisis ditemukan 163 butir tuturan direktif pada film Kokowääh dan 39 butirtuturan pada film ein Freund von mir. Contoh tindak tutur jenis ini yang terdapat dalam film Kokowääh dapat dilihat pada tuturan berikut:
(3) Henry (H) : Katharina! Katharina (K) : Hau ab! Pergi!
$\mathrm{H}$ : Katharina, mach auf! Katharina, buka! (KKW.820,
01.35 .14
01.35.15).

Tuturan ini terjadi ketika Katharina marah pada Henry dan mengusirnya ketika Henry datang menemuinya. Bentuk tuturannya berupa kalimat perintah. Hal ini dapat dilihat dari bentuk kalimat di mana kata kerja terletak di posisi pertama dari kalimat.

\section{4)Tindaktutur ekspresif}

Contoh yang diambil dari film Ein Freund von mir dapat dilihat pada tuturan berikut:

(4) Karl (K): Du darfst auf gar keinen Fall singen. Sag ihm, dass du jeden abend vor demSchlafen gehen mit Gottredest. Bagaimanapunjuga kau tidak boleh bernyanyi. Katakan padanya, kalaukau setiap pergi tidur berdoa pada Tuhan.'

$\begin{array}{ll}\text { Hans }(\mathrm{H}) & \text { : Dem Dicken? } \\ & \text { Yang gemuk? } \\ \mathrm{K} & : \text { Mhm. } \\ \mathrm{H} & \text { :Danke! } \\ & \text { Terima kasih. }\end{array}$

(EFVM.5, 00.09.45-00.09.46).

Hans berterima kasih kepada Karl karena Karl memberikan padanya tips agar dia diterima dalam wawancara kerja. Berterima kasih merupakan kata kerja 
Jurnal Belajar Bahasa, ISSN 2502-5864, E-ISSN 2503-0329

Volume 4, No. 1, Februari 2019

performatif yang termasuk dalam golongan tindak tutur ekspresif.

\section{5)Tindak tutur deklarasi}

Jenis tindak tutur ini yang paling sedikit ditemukan. Tuturan ini ditunjukkan oleh contoh berikut:

(5) Magdalena (M) :Ich versprech's! Aku berjanji! Henry $(\mathrm{H}) \quad$ : Sicher ist sicher. (KKW.567, 01.03.07-01.03.09).

Tuturan ini terjadi ketika Henry memarahi Magdalena karena Magdalena menyebabkan kebakaran dapur pada malam sebelumnya. Tuturan ini mengindikasikan sebuah penetapan, bahwa janji adalah janji, sehingga sebaiknya tidak dilanggar. Berdasarkan hal tersebut tuturan ini dikelompokkan dalam jenis tindak tutur deklarasi.

\section{B. Fungsi pada jenis tindak tutur ilokusi}

Masing-masing tindak tutur di atas mempunyai fungsinya sendiri-sendiri, di antaranya:

\section{Fungsi pada tindak tutur asertif/representatif}

Berikut adalah contoh dari masingmasing fungsi tersebut.

\section{a. Fungsi kompetitif}

Fungsi kompetitif pada tindak tutur asertif/representatif yang diambil dari film Kokowääh ada pada dialog berikut:

(6) Katharina (K): Darf ich zu Ihnen setzen? Anda? Bisa duduk dekat

$\begin{array}{ll}\text { Henry }(\mathrm{H}) & \text { : (Tertawa) } \\ \mathrm{K} & \text { : Was ist? } \\ & \text { Apa? }\end{array}$

(KKW.2, 00.08.20-00.08.22).
Tuturan ini terlontar ketika Henry dan Katharina bertemu di sebuah bar. Melihat kedatangan Katharina, Henry tertawa kecil, sehingga keluarlah tuturan ini dari mulut Katharina sebagai upaya untuk meminta penjelasan atas tawa Henry. Oleh sebab itu tuturan ini dimasukkan dalam fungsi kompetitif karena ada unsur 'meminta' dalam kalimat tanya tersebut.

\section{b. Fungsi menyenangkan}

Selain fungsi kompetitif, pada tindak tutur asertif/representatif terdapat pula fungsi menyenangkan. Pada film ein Freund von mir dapat dilihat contoh berikut:

(7) Karl (K): Du sagst kein Wort, bis wir

bei mir sind! Gute Nacht. Jangankatakan apapun sampai kita di rumahku! Selamat malam.

Hans (H) : Ja, gute Nacht. Ya, selamat malam.

(EFVM.99, 00.26.07-00.26.08).

Tuturan ini terjadi ketika Hans mengantar Karl pulang ke rumahnya. Di saat akan berpisah, Karl berpamitan pada Hans. Karena bentuk tuturan tersebut berupa salam, maka tuturan tadi dapat dikategorikan mempunyai fungsi menyenangkan sebagaimana penjelasan sebelumnya.

\section{c. Fungsi bekerja sama}

Fungsi bekerja sama juga banyak ditemui pada tindak tutur asertif/representatif. Dari film Kokowäähdapat dilihat pada contoh berikut:

(8) Katharina (K) : Ja, und was passiert mit

ihnen? 


$$
\begin{array}{ll}
\text { Ya, dan apa yang } \\
\text { terjadi } & \text { pada } \\
\text { mereka? } &
\end{array}
$$

Henry $(\mathrm{H})$ : Das weib ich noch nicht.

\section{Ich hab 'ne Idee fürs Ende,aber... Ich weibnicht, ob's funktioniert.}

Aku belum tahuitu. Aku punya sebuah ide untuk akhirnya,tapi... aku tidaktahu, apakah itu berfungsi.'

(KKW.683, 01.23.25-01.23.32).

Tuturan yang terdapat dalam film Kokowääh ini terjadi ketika Henry dan Katharina membicarakan cerita burung Kuck Kuck yang pernah diceritakan Henry pada Katharina. Katharina bertanya pada Henry, apakah dalam cerita tersebut tidak ada tokoh wanitanya dan bagaimana kelanjutan cerita tersebut. Tuturan tadi merupakan jawaban Henry atas pertanyaan Katharina. Tuturan tersebut berupa sebuah jawaban dengan maksud untuk mengumumkan atau melaporkan, sehingga dikelompokkan sebagai tuturan yang mempunyai fungsi bekerja sama.

\section{d. Fungsi bertentangan}

Di samping ketiga fungsi tindak tutur di atas, tindak tutur asertif/representatif juga mempunyai fungsi bertentangan. Berikut adalah contoh baik yang diambil dari film ein Freund von mir.

(9) Karl (K) : Mach die Scheißtür auf! Buka pintu sialan ini!

$$
\begin{array}{r}
\text { Hans }(\mathrm{H}) \quad \text { : Ist offen. } \\
\text { Terbuka. }
\end{array}
$$

(EFVM.92, 00.24.39-00.24.41).

Tuturan yang dilontarkan Karl ini terjadi ketika dia dan Hans berada di rumah Stelle. Di sana mereka bertemu dengan mantan pacar Stelle yang marah atas kedatangan mereka berdua. Dengan tergesa-gesa Karl ingin segera pulang ke rumah, dengan marah dia melontarkan tuturan tersebut kepada Hans karena merasa Hans telah mengerjainya. Kata die Scheißtür merupakan gabungan dari kata die Tür dan der Scheib. Die Tür berarti pintu, sedangkan der Scheib dapat dikelompokkan sebagai kata umpatan. Sekiranya kata der Scheib (atau Scheib) dilesapkan, maka kata tersebut akan kehilangan makna umpatan yang menjadi tujuan dari tuturan itu sendiri. Berdasarkan hal tersebut, tuturan ini dikelompokkan dalam tuturan asertif/representatif yang memiliki fungsi bertentangan karena memunyai fungsi mengumpat.

\section{Fungsi pada tindak tutur komisif}

Tindak tutur komisif juga mempunyai empat fungsi, yaitu: fungsi kompetitif, fungsi menyenangkan, fungsi bekerja sama, dan fungsi bertentangan. Berikut adalah penjelasan masing-masing fungsi pada tindak tutur ini.

\section{a. Fungsi kompetitif}

Fungsi ini dapat dilihat pada tuturan berikut:

(10) Katharina (K) : Darf ich mich zu Ihnen

setzen?

Boleh saya duduk dekat Anda?

(KKW.1, 00.08.16-00.08.19).

Tuturan ini diucapkan Katharina ketika dia melihat Henry minum di sebuah bar. Pemakaian kata dürfen 'boleh' dalam bentuk kalimat tanya adalah bentuk 
sebuah permintaan ijin untuk melakukan sesuatu.

\section{b. Fungsi menyenangkan}

Tindak tutur komisif yang mempunyai fungsi menyenangkan bisa dilihat pada contoh berikut:

(11) Magdalena (M) : Das ist sie nicht. Itu bukan kartu tersebut.

Henry $(\mathrm{H})$ : Wollen wir wetten?

$$
\begin{aligned}
& \text { Ah... } \\
& \text { Mau taruhan? } \\
& \text { Ah... }
\end{aligned}
$$

(KKW.966, 01.53.51-01.53.54).

Tuturan ini terjadi manakala Henry dan Magdalena bermain kartu di rumah Henry. Magdalena menebak bahwa kartu yang ada pada Henry bukanlah kartu yang mereka maksud, sehinga Henry mengusulkan pada Magdalena untuk bertaruh. Tuturan yang menunjukkan usulan menggunakan kata kerja modal wollen 'ingin' dalam bentuk kalimat tanya yang mana apabila posisi kata kerja modal tersebut digeser ke posisi kedua tuturan tersebut akan beralih fungsi menjadi kalimat pernyataan dan apabila dilesapkan juga akan menghasilkan kalimat pernyataan.

\section{c. Fungsi bekerja sama}

Fungsi yang ketiga pada tindak tutur komisif adalah fungsi bekerja sama. Dari film ein Freund von mir contoh dari tuturan-tuturan tersebut di antaranya:

(12) Karl (K): Glaubst du an Gott? Kau percaya Tuhan? glücklich?

Hans (H) : Ja, klar! Bist du

Tentu saja! Kau
bahagia?

$\mathrm{K} \quad$ : Ich weiß es nicht.

Aku tidak tahu.

(EFVM.32, 00.16.58-00.17.00).

Tuturan ini terjadi ketika Karl secara tidak sengaja bertemu dengan Hans di pesawat. Karl menjawab atas pertanyaan yang diajukan oleh Hans. Tuturan Karl berupa tuturan yang menyatakan atau mengumumkan pendapatnya atas pertanyaan Hans. Maka dari itu, tuturan tersebut dapat dikelompokkan dalam tuturan yang mempunyai fungsi bekerja sama.

\section{d. Fungsi bertentangan}

Berikut adalah contoh yang bisa dilihat yang diambil dari film Kokowääh:

(13) Henry (H) :Ja. Männer erinnern sich

immer nur an die guten ZeitenundFrauen speichern nur das ab, was schiefgelaufen ist. Ya, lelakiselalu ingat pada waktu yang tepat, dan wanita hanyamengingatapa yang menarik baginya. Katharina (K) : Das stimmt nicht. Itu tidak benar.

$\mathrm{H}$

: Doch. Wollen wir 'nen

Test machen? Unsere

Reise

nachNewYork.

Lho, mau kita tes? Wisata kita ke New York.

(KKW.44, 00.10.31-00.10.33).

Henry bersama Katharina bercakapcakap di kediaman Katharina. Terjadi pertengkaran kecil di antara mereka yang 
mengakibatkan Henry melontarkan tuturan tersebut dengan kesal. Tuturan tersebut berupa usulan sekaligus digunakan untuk memarahi Katharina oleh Henry. Berdasarkan hal tersebut tuturan di atas dikategorikan dalam tuturan yang memiliki fungsi bertentangan pada tindak tutur komisif.

\section{Fungsi pada tindak tutur direktif}

Tindak tutur direktif juga mempunyai fungsi kompetitif, menyenangkan, bekerja sama, dan bertentangan.

a. Fungsi kompetitif

Di antara tuturan-tuturan yang ditemukan adalah sebagai berikut:

(14) Magdalena (M) : Bist du ein bisschen

verrückt? $D a$ ist keiner. Mama hatgesagt,dass du den Brief lesen musst.

Kamu gila?

Tidakada siapasiapa. Kata mama, kamu harus bacasurat tersebut.

(KKW.84, 00.16.17-00.16.23).

Tuturan ini diucapkan oleh Magdalena ketika Henry tidak mempercayai ucapannya. Henry merasa dia sedang dikerjai seseorang. Oleh karena itu Magdalena memintanya membaca surat dari mamanya terlebih dahulu. Kalimat perintah yang dipakai tidak langsung memakai pola kalimat perintah seperti di gramatik bahasa Jerman, melainkan menggunakan kata kerja modal. Selain itu tuturan tersebut berupa kalimat tidak langsung sehingga menggunakan konjungsi dass 'bahwa'. Sekiranya kata dass ini dilesapkan, tidak akan mengubah bentuk kalimat tersebut.

\section{b. Fungsi menyenangkan}

Contoh tindak tutur tersebut dapat dilihat sebagai berikut:

(15) Henry (H) : Hast du Lust, heute Abend

\section{auszugehen?}

Mau jalan-jalan malam ini?'

Magdalena (M) : Immer.

Selalu.

$$
\begin{array}{r}
\text { H So. } \\
\text { Ayo. }
\end{array}
$$

(KKW.982, 01.54.47-01.54.48).

Tuturan ini diutarakan oleh Henry pada saat dia mengajak Magdalena untuk memenuhi undangan Katharina. Tuturan ini dapat disisipi kata kerja yang lebih menunjukkan aktifitas berangkat, misalnya abfahren, losfahren, dan sebagainya.

\section{c. Fungsi bekerja sama}

Contoh tuturan-tuturan ini dapat dilihat sebagai berikut:

(16) Henry (H) : Und jetzt ab ins Bett. Sekarang, ayo ke tempat tidur.

Magdalena (M) : Ich hab aber noch keinen Schlafanzug. Tapi aku tidakpunya piyama.

(KKW.245, 00.33.37-00.33.40).

Tuturan ini bukanlah berbentuk kalimat perintah langsung, melainkan ada perintah yang ada pada tuturan tersebut, tersirat secara implisit. Sedangkan dilihat dari fungsinya tuturan ini berbentuk pernyataan atau laporan. Tuturan ini 
terjadi ketika Henry meminta Magdalena untuk tidur. Magdalena menjawab dengan tuturan tersebut. Secara tersirat dia 'meminta' pada Henry bahwa tanpa piyama dia tidak bisa tidur. Hal ini 'memaksa' Henry untuk menyediakannya.

\section{d. Fungsi bertentangan}

Hal ini dapat dilihat pada contoh berikut:

(17) Katharina (K) : Geh. Geh! Ich will jetzt

$$
\begin{aligned}
& \text { allein sein. } \\
& \text { Pergi. Pergi! } \\
& \text { Sekarang akuingin } \\
& \text { sendiri. }
\end{aligned}
$$$$
\text { (KKW.841, 01.37.23-01.37.27). }
$$

Tuturan di atas terjadi pada saat Henry berada di rumah Katharina. Katharina sedang terluka hatinya ketika mengetahui bahwa Magdalena adalah putri kandung Henry. Dia merasa Henry membohonginya selama ini. Dan dia mengusir Henry ketika Henry sudah berada di rumahnya. Tuturan ini berbentuk kalimat perintah namun digunakan untuk memarahi orang lain, dalam hal ini Henry. Oleh karena itu tuturan semacam ini dikelompokkan dalam tindak tutur direktif yang memiliki fungsi bertentangan.

\section{Fungsi pada tindak tutur ekspresif}

Tidak berbeda dengan tindak tutur sebelumnya, tindak tutur ekspresif juga memiliki fungsi kompetitif, menyenangkan, bekerja sama, dan bertentangan. Berikut adalah contohcontoh tindak tutur ekspresif dengan berbagai fungsinya yang terdapat dalam film Kokowääh dan ein Freund von mir.

\section{a. Fungsi kompetitif}

Berikut adalah contoh yang diambil dari film Kokowääh:

(18) Magdalena (M) : Hm. Hier kriegen ja

die Mäuse
Schatten unter
dieAugen. Was
sollich denn
essen?
Hm. Tikus saja
Cumadapatbaya
ngan di sini. Apa
yang
haruskumakan?

(KKW.259, 00.35.41-00.35.51).

Tuturan ini terucap dari mulut Magdalena ketika dia menginap di rumah Henry dan dia tidak menemukan makanan yang bisa dimakan untuk sarapan. Dia mengungkapkan perasaannya dengan sebuah ungkapan atau sebuah pernyataan, di sisi lain dia juga menanyakan apa yang bisa dimakannya. Dalam hal ini dia bermaksud meminta makanan pada Henry. Sehingga dapat dikatakan pernyataan ini memunyai fungsi meminta.

\section{b. Fungsi menyenangkan}

Contoh yang diambil dari film ein Freund von mir sebagai berikut:

(19) Stelle (S) : Hallo!

Hallo!

Hans (H) : Du siehst gut aus! Kau terlihat baik!

S : Hallo, mein Hansimann! Hallo, Hansimann-ku! (EFVM.56, 00.19.15-00.19.17).

Tuturan berupa sapaan ini diungkapkan Stelle ketika dia menerima 
kedatangan Karl dan Hans. Menyapa dapat dikategorikan ke dalam tuturan yang memunyai fungsi menyenangkan.

c. Fungsi bekerja sama

Fungsi ini dapat dilihat pada tuturan berikut:

(20) Henry (H) : So, Magdalena, jetzt legst

du die Kette zurück, dann ist der Papafröhlich.

So, Magdalena, sekarang letakkan (permen) kalung itukembali,buat papamu senang.

Tristan (T) : Du versuchst meine Erziehungzu konterkarieren. Das wird dirnicht gelingen. Kau berusaha melawan didikanku. Itu takkan berhasil.

(KKW.948, 01.52.08-01.52.11).

Tuturan tersebut diucapkan oleh Tristan manakala dia merasa Henry merusak caranya mendidik kepada Magdalena. Dia tidak ingin hasil didikannya dirusak Henry, maka dari itu dia mengeluarkan kritikan dengan menyatakan pernyataan tersebut. Berdasarkan hal tersebut tuturan ini dimasukkan dalam kelompok tuturan yang memiliki fungsi bekerja sama pada tindak tutur ekspresif.

\section{d. Fungsi bertentangan}

Contoh tuturan-tuturan tersebut dapat dilihat sebagai berikut:

(21) Henry (H): Blöder Wichser, ey. Dasar bodoh, ha. (KKW.532, 01.00.19-01.00.20).
Tuturan berupa umpatan itu dilontarkan Henry ketika ada seorang polisi menilangnya sepulang menjemput Magdalena dari sekolah. Dia mengungkapkan kemarahannya dengan mengumpati polisi tersebut. Tuturan semacam ini dikelompokkan dalam tindak tutur ekspresif yang memiliki fungsi bertentangan. Contoh berikutnya dapat dilihat dalam film ein Freund von mir.

\section{Fungsi pada tindak tutur deklarasi}

Sama halnya dengan tindak tutur sebelumnya, tindak tutur deklarasi juga mempunyai fungsi yang sama, yaitu: fungsi kompetitif, menyenangkan, bekerja sama, dan bertentangan.

\section{a. Fungsi kompetitif}

Pada tindak tutur ini tidak ditemukan adanya fungsi kompetitif baik dalam film Kokowääh maupun dalam film ein Freund von mir. Meskipun demikian tidak menutup kemungkinan di lain film akan ditemukan fungsi ini pada tindak tutur deklarasi.

\section{b. Fungsi menyenangkan}

Fungsi menyenangkan pada tindak tutur deklarasi tidak ditemukan baik di dalam film Kokowääh maupun di dalam film ein Freund von mir. Tidak menutup kemungkinan bahwa di lain film fungsi ini dapat ditemukan pada tindak tutur deklarasi.

\section{c. Fungsi bekerja sama}

Salah satu contoh yang diambil dari film Kokowääh adalah sebagai berikut:

(22) Magdalena (M): Wir sind da!

Kita di sini!

Henry $(\mathrm{H}) \quad$ : Geh jetzt mal in die

Schule, komm! 
Sekarang pergi kesekolah, ayo!

(KKW.622, 01.15.07-01.15.10).

Tuturan ini terjadi pada saat Magdalena tiba di sekolah dengan diantar Henry. Mereka pergi ke sekolah dengan terburu-buru karena terlambat sehingga begitu tiba di sekolah, Magdalenamengekspresikan

kegembiraannya dengan tuturan tersebut. Maka dari itu tuturan ini dapat dikelompokkan dalam tuturan yang memiliki fungsi bekerja sama pada tindak tutur deklarasi.

\section{d. Fungsi bertentangan}

Contoh ini diambil dari film Kokowääh dapat diperhatikan sebagai berikut:

(23) Tristan ( $T$ ) : Ich muss sagen, sie sieht

Ihnen verblüffend ähnlich. Wiekonnteich nur so blind sein?

Saya harus mengatakan, diatampak mirip dengan

Anda.Bagaimana saya bisa begitu buta?'

(KKW.146, 00.23.10-00.23.17).

Tristan mengutarakan tuturan ini pada Henry ketika mereka bertemu pertama kali di tempat prakteknya. Dia mengatakan bahwa Magdalena mirip dengan Henry. Hal tersebut diucapkan sebagai sebuah tuduhan bahwa Henrylah yang merusak kehidupan tumah tangganya. Tunduhan tersebut diungkapkan dengan tuturan berupa sindiran Wie konnte ich nur so blind sein?'Bagaimana saya bisa begitu buta?’. Berdasarkan hal ini maka tuturan tersebut dimasukkan dalam kelompok tindak tutur deklarasi yang memiliki fungsi bertentangan.

\section{Prinsip Kesantunan Leech dalam tindak tutur ilokusi}

Prinsip kesantunan yang dijabarkan oleh Leech mempunyai enam jenis maksim. Keenam jenis maksim tersebut adalah maksim kearifan (tact maxim), maksim kedermawanan (generosity maxim), maksim pujian (approbation maxim), maksim kerendahan hati (modesty maxim), maksim kesepakatan (agreement maxim), dan maksim kesimpatian (sympath maxim).

\section{Maksim Kearifan (Tact Maxim)}

Contoh tuturan tersebut adalah sebagai berikut:

(24) Henry (H): Komm, gib her. Ich mach

das für dich.

Ayo, berikanpadaku.

Aku yang mengerjakan.

Magdalena (M): Ich kann's alleine.

Aku bisa sendiri.

(KKW.204, 00.31.04-00.31.05).

Tuturan ini diucapkan oleh Magdalena pada saat dia menolak bantuan dari Henry untuk mengerjakan pekerjaan rumahnya. Dengan mengucapkan tuturan tersebut, dia memosisikan Henry agar mendapatkan keuntungan sebesar mungkin dengan tidak mengerjakan tugas rumahnya. Berdasarkan hal tersebut, tuturan ini dikategorikan memiliki maksim kearifan.

\section{Maksim Kedermawanan (Generosity Maksim)}

Contohtuturan ini dapat dilihat sebagai berikut: 
(25) Magdalena (M): Und ich brauch einen

Bikini.

Dan aku juga perlu bikini.

Tristan ( $\mathrm{T}$ ) :Wozu? Da ist noch gar

nichts...

Untuk apa?

Itubenar-benar

tidak...

M : Einen orangenen

mit

grünen Punkten.

Yang totol oranye dan hijau.

$\mathrm{T} \quad$ : Orange mit

grünen

Punkten. Klar, notiert.

Totol oranye dan hijau. Baiklah, kucatat.

(KKW.888, 01.43.12-01.43.13).

Tuturan yang diucapkan Tristan ini dikelompokkan ke dalam tuturan yang memiliki maksim kedermawanan. Hal ini dikarenakan dia menuruti keinginan Magdalena yang menginginkan baju renang baru dengan motif tersebut. Dia dengan kerelaannya membuat kerugian bagi dirinya dengan menuruti permintaan Magdalena.

\section{Maksim Pujian (Approbation maxim)}

Hal ini dapat diperhatikan pada tuturan berikut:

(26) Stelle (S): Kuchen.

Cake.

Hans (H): Danke dir. Lecker! Hier, probier mal. Hmm! Super!

Terimakasih. Lezat! Ini, cobalah. Hmm! Super!

(EFVM.70, 00.20.20-00.20.28).
Tuturan yang terjadi pada saat Hans dan Karl dijamu dengan cake oleh Stelle ini mengandung maksim pujian. Pujian Hans terhadap cake yang disuguhkan termasuk salah satu bentuk kesantunan berbahasa baik karena cake itu memang enak, maupun pujian itu hanya untuk menyenangkan Stelle.

\section{Maksim Kerendahan Hati (Modesty} Maxim)

Berikut tuturan yang diambil dari film Kokowääh sebagai contoh:

$\begin{array}{ll}\text { (27) Charlotte } & \text { (C) :Wie geht's }\end{array}$ Magdalena?

Apa kabar Magdalena?

Tristan (T) : Ganz gut, glaube ich. Baik menurutku.

\section{C : Es tut mir so leid.} Maafkan aku. (KKW.665, 01.21.56-01.21.57).

Tuturan ini berasal dari Charlotte ketika dia menghubungi Tristan dan menanyakan kabarnya dan kabar Magdalena. Dia merasa bersalah karena meninggalkan mereka ke Amerika. Dengan meminta maaf dia berusaha merendahkan dirinya sendiri. Maka dari itu tuturan ini dikategorikan mempunyai maksim kerendahan hati.

\section{Maksim Kesepakatan (Agreement Maxim)}

Hal ini dapat dilihat pada tuturan berikut:

(28) Stelle (S): Und wie nennt er sie?

Dan bagaimana dia memanggilnya?

Hans (H): Bernd!

Bernd!

Karl (K) : Stimmt.

Tepat.

(EFVM.176, 00.40.12-00.40.13). 
Tuturan ini dilontarkan oleh Karl pada saat Hans menebak nama orang yang dimaksud oleh Karl. Karl membenarkan jawaban tersebut dengan tuturan di atas. Maka dari itu tuturan ini dikelompokkan sebagai tuturan yang memiliki maksim kesepakatan.

\section{Maksim Kesimpatian (Sympath Maxim)}

Tuturan berikut dapat diperhatikan sebagai contoh:

(29) Magdalena (M): Warum bist du denn

so traurig?
Mengapa kau
begitu sedih?
Katharina $(\mathrm{K})$ : Ich bin doch nicht
traurig.
Aku tidak sedih.

(KKW.797, 01.32.13-01.32.17).

Tuturan ini diucapkan Magdalena pada saat dia melihat Katharina tiba-tiba sedih setelah mendengar cerita darinya. Dari sini terlihat bahwa Magdalena menunjukkan kesimpatiannya pada Katharina, oleh karena itu tuturan ini dimasukkan dalam kelompok tuturan yang memiliki maksim kesimpatian.

\section{Skala Kesantunan}

Skala kesantunan Leech yang dipakai untuk menganalisis tuturan dalam film Kokowääh dan ein Freund von mir adalah skala kemanasukaan. Skala ini menitik beratkan pada adanya pilihan bagi lawan tutur untuk melakukan atau tidak melakukan tindakan yang diinginkan oleh penutur. Skala kemanasukaan di sini dibagi menjadi tiga, yaitu: rendah, sedang, dan tinggi. Skala tersebut dikatakan rendah apabila lawan tutur tidak mempunyai pilihan untuk tidak melakukan tindakan yang diinginkan oleh penutur. Dikatakan sedang bila lawan tutur dapat memilih untuk melakukan atau tidak melakukan tindakan yang diinginkan oleh penutur dan dikatakan tinggi apabila lawan tutur dapat bebas menentukan tindakan yang akan dilakukannya. Berikut adalah hasil yang diperoleh dari analisis dari kedua film.Contoh tuturan dengan skala kesantunan rendah tersebut adalah sebagai berikut:

(30) Henry (H):Komm, gib her. Ich mach das für dich.

Ayo, berikan padaku. Aku yang mengerjakan.

Magdalena (M): Ich kann's alleine. Aku bisa sendiri.

$\mathrm{H}$

\section{: Komm her.}

Kemarikan.

(KKW.205, 00.31.04-00.31.05).

Tuturan ini terjadi ketika Henry meminta Magdalena menyerahkan pekerjaan rumahnya pada Henry. Awalnya Magdalena menolak, tetapi ketika Henry mengucapkan tuturan di atas, mau tidak mau Magdalena menyerahkan tugasnya. Dalam hal ini skala kemanasukaan yang dimiliki Magdalena rendah karena dia tidak bisa memilih tindakan yang ingin dilakukannya. Suka ataupun tidak, dia harus melakukan apa yang diperintahkan oleh Henry.Contoh tuturan dengan tingkat kemanasukaan sedang dapat dilihat sebagai berikut:

(31) Henry (H): Soll ich dir 'n Eis von der Tanke mitbringen? Maukubawakan es dari Tanke? 
Magdalena (M): Ich will kein Eis von

der Tanke, ich
will, dass duhier
bleibst.Du stinkst
nach Rauch.
Aku tidak mau es
dariTanke, aku
ingin, kamu
tetap di
sini.Kamu bau
rokok.

(KKW.814, 01.33.46-01.33.48).

Tuturan ini ditujukan Henry kepada Magdalena. Dia ingin mengejar Katharina yang marah dan sedih karena mengetahui kenyataan siapa Magdalena sebenarnya. Meskipun demikian Magdalena melarangnya mengikuti Katharina, oleh karena itu Henry membujuknya dengan tuturan di atas. Pada situasi seperti ini, Magdalena mempunyai pilihan yang terbatas atas pertanyaan Henry tersebut. Pilihan dia adalah menerima tawaran es tersebut atau menolaknya. Maka dari itu dapat dikatakan tingkat skala kemanasukaannya sedang.

Yang ketiga adalah skala kemanasukaan tingkat tinggi.Sebagai contoh perhatikan tuturan berikut:

(32) Karl (K) : Nach Hause. Können wir einfach mal kurz nicht reden?

Pulang.Bisa kita tidak bicara sebentar?

Hans (H): Klar, kein Problem.

Tentu, tidak masalah.

(EFVM.43, 00.17.51-00.17.52).

Tuturan ini bersumber dari Hans. Pada saat Hans mengantar Karl pulang, dia terlalu banyak bicara, sehingga Karl memintanya untuk diam. Menanggapi permintaan Karl, Hans menjawab dengan tuturan di atas. Setelah pernyataan Hans tersebut, Karl dapat dengan bebas menentukan tindakan selanjutnya.

\section{SIMPULAN}

Berdasarkan analisis yang dipaparkan sebelumnya, diperoleh hasil sebagai berikut sesuai urutan rumusan masalah: (1) jenis tindak tutur yang terdapat dalam film tersebut (sesuai dengan urutan yang paling banyak) adalah asertif/representatif, ekspresif, direktif, komisif, dan deklarasi (Kokowääh) dan asertif/representatif, direktif, ekspresif, komisif, dan deklarasi (Ein Freund von mir). (2) fungsi tindak tutur ilokusi yang didapat mempunyai jumlah berbedabeda bergantung pada jenis tindak tutur ilokusinya baik pada film Kokowääh maupun pada film ein Freund von mir. (3) prinsip kesantunan yang paling banyak digunakan dalam kedua film tersebut maksim kesepakatan diikuti oleh maksim lainnya, yaitu kearifan, pujian, kedermawanan, kerendahan hati, dan kesimpatisan (Kokowääh) atau pujian, kedermawanan, kearifan, kerendahan hati, dan kesimpatisan (Ein Freund von mir). (4) skala kesantunan yang digunakan adalah skala kemanasukaan dengan hasil didominasi oleh skala kemanasukaan tinggi.Maka dari itu dapat disimpulkan bahwa tuturan-tuturan dalam kedua film tersebut banyak berupa pernyataan yang mempunyai fungsi yang berbeda-beda tergantung dengan konteks di mana tuturan tersebut terjadi. Dari tuturantuturan tersebut diketahui bahwa maksim kesepakatanlah yang banyak digunakan dalam bersopan santun dengan skala 
Mirfat. Prinsip Kesantunan Dalam Fungsi Tindak Tutur....

Jurnal Belajar Bahasa, ISSN 2502-5864, E-ISSN 2503-0329

Volume 4, No. 1, Februari 2019

kesantunan kemanasukaan tinggi, di

mana lawan tutur dapat dengan bebas

menentukan tindakan berikutnya.

\section{DAFTAR PUSTAKA}

Arikunto, S. (2010).

Prosedurpenelitian:SuatuPendekatanP

raktik. (EdisiRevisi).

Jakarta:RinekaCipta.

Austin, John. L. 1962. How to Do Things with Words. London: Oxford University Press.

Brown, Gillian dan George Yule. 1996. Analisis Wacana. Jakarta: PT Gramedia Pustaka Utama.

Leech, G. (1993). Prinsip-prinsip Pragmatik. Jakarta: UI Press.

Mahsun.

(2005).

MetodePenelitianBahasa

"TahapanStrategi,

Metode, danTekniknya".Jakarta:

PT.RajaGrafindoPersada.

Nadar, F.X.(2009). Pragmatik dan Penelitian Pragmatik. Yogyakarta: Graha IImu.

Rani, Abdul, Bustanul Arifin dan Martutik. 2006. Analisis Wacana- Sebuah Kajian Bahasa Dalam Pemakaian. Malang: Bayu Media Publishing.

Searle, J. R. (1997). Speech Act. Melbourne : Cambridge University Press.

Sudaryanto. (2015). Metode dan Aneka Teknik Analisis Bahasa. Yogyakarta. Sanata Dharma University Press.

Yule, G. (2006).Pragmatik. Yogyakarta: Pustaka Pelajar. 